\title{
KOMUNIKASI KELUARGA DALAM MENINGKATKAN MOTIVASI BELAJAR ANAK
}

\author{
Zulin Nurchayati \\ Fakultas Ilmu Sosial dan Ilmu Politik Universitas Merdeka Madiun \\ Email: zulinnurchayati@gmail.com
}

\begin{abstract}
Abstrak
Education in the family is the basis of children's education. The process should be supported by family members, especially the parents. Hence, the communication within family motivates and becomes reinforcement in learning process as well as weapon in encountering the problems so that all resolution can be obtained.
\end{abstract}

Kata kunci: Family, Communication, Learning Motivation.

\section{Pendahuluan}

Komunikasi bagi manusia sebagai makhluk sosial mempunyai kedudukan yang sangat asasi dalam perjalanan hidupnya, karena dengan komunikasi manusia akan memenuhi segala kebutuhan hidupnya, baik kebutuhan lahir maupun kebutuhan batin. Dengan komunikasi manusia akan membentuk kasih sayang, membina persahabatan, menyebarkan pengetahuan dan melestarikan peradaban dan kebudayaan. Hal ini merupakan kebutuhan yang tidak bisa ditawar lagi. Akan tetapi komunikasi bukan hanya mempunyai dampak positif bila komunikasi tidak dilakukan dengan cara yang benar. Komunikasi sangat urgent dan sangat diperlukan kehadirannya dalam lingkungan keluarga karena keluarga adalah merupakan ajang pembentuk watak dan kematangan pribadi anak.

Dari pernyataan diatas dapat dilihat bahwa keluarga merupakan wahana bagi anak dalam perkembangan jiwa dan kematangan pribadi anak dalam menjalani hidupnya kelak. Menurut soeleman dalam bukunya moh. Schohib keluarga adalah sekumpulan orang yang hidup bersama dalam tempat tinggal yang sama dan masing masing anggota 
merasakan pertautan batin sehingga terjadi saling mempengaruhi dan saling memperhatikan. ${ }^{1}$

Sebagaimana pernyataan diatas bahwa keluarga atau dalam bentuk "Rumah Tangga" adalah satu unit terkecil yang mempunyai kedudukan sangat penting di masyarakat dan Negara, sebab suasana "Rumah Tangga “yang sejahtera dapat mempertinggi mutu atau nilai kehidupan dan memperkokoh terbinaya suatu Negara yang adil, makmur dan bahagia dengan tercapainya kesejahteraan ditengah masyarakat. Rumah tangga yang sejahtera yang diliputi oleh cinta dan kasih sayang yang sangat didambakan oleh semua orang. Kasih sayang orang tua merupakan harapan utama anak dalam meniti kehidupan, seperti dalam belajar orang tua berperan penting, karena belajar merupakan start awal untuk memulai keberhasilan dalam berprestasi.

Dalam meraih prestasi anak perlu belajar dan berusaha untuk mencapai keberhasilan dalam belajarnya, tetapi penulis banyak melihat di lingkungan Desa Ketandan, Kecamatan Dagangan yang mana wilayah penulis teliti, sebelum penelitian penulis sering melihat banyak sekali anak-anak usia pelajar pada waktu jam-jam belajar tidak digunakan untuk belajar melainkan digunakan untuk bermain, nonton tv bahkan ada yang di persewaan play station.

Dengan adanya masalah ini banyak dikemukakan para ahli dalam teori belajar, Menurut W. Gulo belajar adalah suatu proses yang berlangsung di dalam diri seseorang yang mengubah tingkah laku dalam berfikir bersikap dan berbuat. ${ }^{2}$ Sedangkan menurut Syaiful Bahri belajar adalah suatu kegiatan yang kita lakukan untuk memperoleh sejarah ilmu pengetahuan". 3

Dalam rangka untuk menghantar pendidikan kearah kedewasaan

\footnotetext{
${ }^{1}$ Moh Shochib, Pola Asuh Orang Tua (Jakarta: PT. Rineka Cipta, 1998), 67.

2 W. Gulo. Straregi Belajar Mengajar (PT. Grasindo, Jakarta,2002), 56.

${ }^{3}$ Syaiful Bahri Djamarah, Rahasia sukses belajar, (Rineka Cipta, Jakarta,2002), 49.
} 
yang sepadan dengan kebutuhan bermasyarakat. Mengingat anak bukanlah objek pendidikan, tetapi mereka membawa potensi masingmasing yang akan diarahkan di dalam pendidikan kehidupan sehingga mereka dapat berkembang sesuai dengan kemajuan jaman. Anak merupakan generasi penerus dari generasi sebelumnya yang kelak akan mengisi pembangunan di keluarga, masyarakat dan Negara.

Oleh karena itu orang tua yang pertama harus memberikan motivasi bagi anak, agar anak dapat lebih berprestasi dalam pendidikannya.

Moh. Uzer Usman mengemukakan bahwa motivasi adalah kekuatan tersembunyi dalam diri kita yang mendotong kita untuk berkelakuan dan bertindak dengan cara yang khas. ${ }^{4}$

Dengan demikian maka pendidikan keluarga adalah fundamental atau dasar dari pendidikan yang dibarengi oleh motivasi dari keluarga khususnya orang tua. Oleh karena itu adanya komunikasi keluarga akan sangat membantu memotifasi dan menjadi pendorong dalam belajar dan menghadapi massalahmasalah yang akan dipecahkan bersama.

\section{Pembahasan}

\section{Komunikasi Keluarga}

Dari teori Sulur JS komunikasi keluarga termasuk komunikasi antar personal dapat kita lihat komunikasi keluarga merupakan penyampaian berita, informasi, pesan dari satu anggota keluarga agar dimengerti dan dipahami oleh seluruh anggota keluarga. Dan komunikasi keluarga mempunyai indicatorindikator atau dimensi yang mempengaruhi intensitas komunikasi keluarga yakni sebagai berikut:

Keterbukaan adalah kemampuan untuk membuka atau mengungkapkan pikiran, perasaan, dan reaksi kita kepada orang lain. Kita harus melihat bahwa diri kita dan pembukaan diri yang akan kita

\footnotetext{
${ }^{4}$ www.google.com/teori motivasi.
} 
lakukan tersebut diterima orang lain, kalau kita sendiri menolak diri kita (self rejectimg), maka pembukaan diri kita akan kita rasakan terlalau riskan. Selain itu, demi penerimaan diri kita maka kita harus bersikap tulus, jujur, dan authentic dalam membuka diri. Pada hakekatnya setiap manusia suka berkomunikasi dengan manusia lain, karena itu tiap-tiap orang selalau berusaha agar mereka lebih dekat satu sama lain. Faktor kedekatan atau proximity bisa menyatakan dua orang yang mempunyai hubungan yang erat. Kedekatan antar pribadi mengakibatkan seseorang bisa dan mampu menyatakan pendapat-pendapatnya dengan bebas dan terbuka. Keterbukaan di sini adalah bersikap terbuka dan jujur mengenai perasaan/pemikiran masing-masing, tanpa adanya rasa takut dan khawatir untuk mengungkapkannya.

Empati merupakan kemudahan dalam melakukan komunikasi yang baik. Komunikasi yang baik antara orang tua dengan anak akan menjadikan anak merasa dihargai sehingga anak akan merasa bebas mengungkapkan perasaan serta keinginannya. Hal ini dapat dijalankan dengan membuat komunikasi dalam keluarga sportif dan penuh kejujuran, setiap pernyataan yang di utarakan realistis, masuk akal dan tidak dibuat-buat, selain itu komunikasi di dalam keluarga harus diusahakan jelas dan spesifik, setiap anggota keluarga benar-benar mengenal perilaku masing-masing, dan semua elemen keluarga harus dapat belajar cara tidak menyetuji tanpa ada perdebatan yang destruktif.

Untuk membangun dan melestarikan hubungan dengan sesama anggota keluarga, kita harus menerima diri dan menerima orang lain. Semakin besar penerimaan diri kita dan semakin besar penerimaan kita terhadap orang lain, maka semakin mudah pula kita melestarikan dan memperdalam hubungan kita dengan orang lain tersebut. ${ }^{5}$

${ }^{5}$ Alo Liliweri, Komunikasi Antar Pribadi, (PT. Citra Aditia Bakti,1997), 86. 
Ada beberapa prinsip yang dapat digunakan dalam mendukung komunikasi keluarga, sehubungan komunikasi antar orang tua dengan anak-anak:

1. Bersedia memberikan kesempatan kepada anggota keluarga yang lain sehingga pihak lain berbicara.

2. Mendengarkan secara aktif apa yang dibicarakan pasangan bicara.

3. Mengajari anak-anak untuk mendengarkan.

4. Menyelesaikan konflik secara dini sehingga terjalin komunikasi yang baik. Thomas Gordon dalam Farida Lestira. ${ }^{6}$

Sebuah komunikasi akan dikatakan sukses kalau komunikasi tersebut menghasilkan sesuatu yang diharapkan yakni kesamaan pemahaman. Perselisihan dan perbedaan paham akan menjadi sumber persoalan bila tidak ditangani dengan bijaksana, sehingga memerlukan usaha-usaha komunikatif antara anggota keluarga.

Dalam usaha untuk menyelesaikan persoalan maka pemikiran harus dipusatkan dan ditujukan ke arah pemecahan persoalan, supaya tidak menyimpang dan mencari kekurangan-kekurangan dan kesalahankesalahan masing-masing.

Oleh karena itu, sebuah komunikasi harus dilakukan secara konstruktif dan dengan dasar kasih sayang. Keakraban dan kedekatan antara orang tua dengan anak-anaknya membuat komunikasi dapat berjalan secara efektif dalam meletakkan dasar-dasaruntuk berhubungan secara akrab dan dekat. Kemampuan orang tua dalam melakukan komunikasi akan efektif karena orang tua dapat membaca dunia anaknya (selera, keinginan, hasrat, pikiran, dan kebutuhan).

Beberapa ahli menyebutkan unsur-unsur komunikasi dalam keluarga sama dengan unsur-unsur komunikasi pada umumnya. Hafied

\footnotetext{
${ }^{6}$ Gordon, Thomas, Menjadi Orang Tua efektif, Petunjuk Terbaru MendidikAnak yang Bertanggung Jawab, (Jakarta: PT Gramedia Pustaka Utama , 1991), 90.
} 
Cangara merangkum pendapat para ahli, beberapa unsur komunikasi yang dapat diterapkan untuk komunikasi dalam keluarga, yang pertama adalah: Sumber komunikasi, maksudnya adalah pembuat atau pengirim informasi dalam komunikasi keluarga. Dalam komunikasi keluarga sumber bisa berasal dari ayah, ibu, adik, bahkan lebih luas lagi kakek, nenek, bibi, paman, dan sebagainya. Kedua adalah pesan, Pesan yang disampaikan dalm proses komunikasi dalam keluaraga dapat disampaikan dengan cara tatap muka di dalam rumah atau melalui media komunikasi bila tidak bertemu di rumah. Isi pesan bisa berupa ilmu pengetahuan (misalnya ketika anak menanyakan isi PR), hiburan (misalnya orang tua menyanyikan lagu untuk si kecil), informasi (misalnya tentang berbagai berita lokal maupun nasional), atau nasehat yang berguna (misalnya dalam memilih teman bergaul). Ketiga, adalah media. Media yang di maksud ialah alat yang digunakan umtuk memindahkan pesan dari sumber kepada penerima. Terdapat beberapa saluran atau media komunikasi. Media komunikasi utama untuk komunikasi dalam keluarga adalah pancaindra manusia, pada saat anggota keluarga dapat bertemu langsung. Selain indera manusia, ada juga saluran komunikasi yang dapat digunakan pada saat anggota keluarga tidak dapat bertemu muka, yaitu melalaui surat, telepon, telegram, ponsel, hingga internet. Keempat adalah penerima. Penerima adalah pihak yang menjadi sasaran pesan. Di dalam keluarga, penerima pesan adalah semua anggota keluarga. ${ }^{7}$

Unsur lain adalah pengaruh atau efek pesan baik dari pengetahuan, sikap atau tingkah laku seseorang". menjelaskan ruang lingkup komunikasi keluarga terdiri atas unsur-unsur: (a) bentuk, (b) sifat (c) metode, (d) fungsi, (e) tujuan. ${ }^{8}$

\footnotetext{
${ }^{7}$ Cangara, Hafied, Pengantar Ilmu Komunikasi (Jakarta: Raja Grafindo Persada 2002), 43.

${ }^{8}$ Op.Cit, 67.
} 
Unsur-unsur tersebut dalam kaitannya dengan komunikasi keluarga diuraikan sebagai berikut: Bentuk komunkasi dalam keluarga adalah personal communication yaitu komunikasi antar pribadi. Sifat komunikasi dalam keluarga dapat verbal maupun non-verbal. Secara verbal yaitu dengan ucapan dan tulisan, adapun secara non-verbal yaitu dengan tindakan atau gerak mimik. Metode komunikasi dalam keluarga adalah informasi, persuasive, dan instruktif. Fungsinya adalah untuk memberikan informasi, edukasi, persuasi, dan hiburan.

Tujuan komunikasi dalam keluarga adalah perubahan sosial, partisipasi sosial, perubahan sikap, perubahan opini dan juga perubahan tingkah laku. Oleh karena itu, komunikasi dalam keluarga bersifat fundamental. Termasuk, komunikasi yang dilakukan dengan tujuan pendidikan, dalam hal ini, guna meningkatkan motivasi belajar. Keluarga memiliki peran sentral dalam pendidikan seorang anak. Suasana dalam keluarga dan motivasi yang ditebarkan keluarga adalah kunci melakukan pendidikan yang baik.

\section{Motivasi}

Perkataan motivasi adalah berasal daripada perkataan Bahasa Inggris (motivation) Perkataan asalnya ialah (motive) yang juga telah dipinjam oleh Bahasa Melayu / Bahasa Malaysia kepada motiv, yakni bermaksud tujuan. Di dalam surat khabar, kerap pemberita menulis ayat "motif pembunuhan". Perkataan motif di sini boleh kita fahami sebagai sebab atau tujuan yang mendorong sesuatu pembunuhan itu dilakukan. Motivasi adalah dorongan psikologis yang mengarahkan seseorang ke arah suatu tujuan. Motivasi membuat keadaan dalam diri individu muncul, terarah, dan mempertahankan perilaku.

Dari penjelasan diatas disini ada beberapa pengertian menurut para ahli diantaranya sebagai berikut. Menurut Kartini Kartono, motivasi menjadi dorongan (driving force) terhadap seseorang agar mau 
melaksanakan sesuatu. ${ }^{9}$ Sedangkan menurut Wexley \& Yukl dalam As'ad, motivasi adalah pemberian atau penimbulan motif, dapat pula diartikan hal atau keadaan menjadi motif. ${ }^{10}$ Ada lagi menurut Mitchell dalam Winardi, motivasi mewakili proses-proses psikologikal, yang menyebabkan timbulnya, diarahkanya, dan terjadinya persistensi kegiatan- kegiatan sukarela (volunter) yang diarahkan ke tujuan tertentu. ${ }^{11}$

Sedangkan menurut Gray dalam Winardi, motivasi merupakan sejumlah proses, yang bersifat internal, atau eksternal bagi seorang individu, yang menyebabkan timbulnya sikap antusiasme dan persistensi, dalam hal melaksanakan kegiatan-kegiatan tertentu. ${ }^{12}$ Morgan dalam Soemanto, mengemukakan bahwa, motivasi bertalian dengan tiga hal yang sekaligus merupakan aspek- aspek dari motivasi. Ketiga hal tersebut adalah: keadaan yang mendorong tingkah laku (motivating states), tingkah laku yang di dorong oleh keadaan tersebut (motivated behavior), dan tujuan dari pada tingkah laku tersebut (goals or ends of such behavior). ${ }^{13}$

Sedangkan McDonald dalam Soemanto, mendefinisikan motivasi sebagai, perubahan tenaga di dalam diri seseorang yang ditandai oleh dorongan efektif dan reaksi- reaksi mencapai tujuan. Motivasi merupakan masalah kompleks dalam organisasi, karena kebutuhan dan keinginan setiap anggota organisasi berbeda satu dengan yang lainnya. Hal ini berbeda karena setiap anggota suatu organisasi adalah unik secara biologis maupun psikologis, dan berkembang atas dasar proses belajar yang berbeda pula menurt Suprihanto, secara umum mendefinisikan motivasi sebagai suatu perubahan tenaga yang ditandai oleh dorongan efektif dan reaksi- reaksi pencapaian tujuan. Karena kelakuan manusia itu selalu bertujuan, kita dapat menyimpulkan bahwa perubahan tenaga yang

\footnotetext{
${ }^{9}$ www.google.com/teori motivasi.

${ }^{10} \mathrm{Ibid}$

${ }^{11} \mathrm{Ibid}$

12 Ibid

${ }^{13} \mathrm{Ibid}$
} 
memberi kekuatan bagi tingkahlaku mencapai tujuan, telah terjadi di dalam diri seseorang. Motivasi adalah suatu proses untuk menggiatkan motif-motif menjadi perbuatan atau tingkah laku untuk memenuhi kebutuhan dan mencapai tujuan atau keadaan dan kesiapan dalam diri individu yang mendorong tingkah lakunya untuk berbuat sesuatu dalam mencapai tujuan.

Motivasi adalah kekuatan tersembunyi di dalam diri kita yang mendorong kita untuk berkelakuan dan bertindak dengan cara yang khas. ${ }^{14}$ Begitu juga dengan Davies, Ivor K, motivasi adalah usaha-usaha untuk menyediakan kondisi-kondisi sehingga anak itu mau melakukan sesuatu". ${ }^{15}$

Secara ringkas, yang dimaksud motivasi adalah bermaksud sebab, tujuan atau pendorong, maka tujuan seseorang itulah sebenarnya yang menjadi penggerak utama baginya berusaha keras mencapai atau mendapat apa juga yang diinginkannya sama ada secara negatif atau positif. Oleh itu kita dapat definisikan bahwa:

Motivasi adalah sesuatu yang menggerak dan mengarahkan terhadap tujuan seseorang dalam tindakan-tindakannya sama ada secara negatif atau positif. Dan Motivasi adalah merupakan sejumlah prosesproses psikologikal, yang menyebabkan timbulnya, diarahkanya, dan terjadinya persistensi kegiatan- kegiatan sukarela (volunter) yang diarahkan ke tujuan tertentu, baik yang bersifat internal, atau eksternal bagi seorang individu, yang menyebabkan timbulnya sikap antusiasme dan persistensi. Fungsi motivasi dalam pembelajaran diantaranya adalah: Mendorong timbulnya tingkah laku atau perbuatan, tanpa motivasi tidak akan timbul suatu perbuatan misalnya belajar. Motivasi berfungsi sebagai pengarah, artinya mengarahkan perbuatan untuk mencapai tujuan yang

\footnotetext{
${ }^{14} \mathrm{Ibid}$

${ }^{15}$ http://id.wikipedia.org/wiki/Motivasi,http://duniapsikologi.dagdigdug.com/2008/1 $1 / 19 /$ pengertia n-motivasi/
} 
diinginkan. Motivasi berfungsi sebagai penggerak, artinya menggerakkan tingkah laku seseorang. Besar kecilnya motivasi akan menentukan cepat atau lambatnya suatu pekerjaan.

\section{Pengertian Belajar}

Segala sesuatu dalam sebuah pekerjaan yang kita kerjakan tidak lepas dari belajar. Maka belajar tidak hanya dilakukan oleh pelajar dan anak tetapi kita seluruh anggota keluarga, agar terciptanya keluarga yang bahagia dan sejahtera. Setiap orang menjadi dewasa karena belajar dan pengalaman selama hidupnya. Belajar merupakan hakikat dan tujuan seseorang sejak mereka ada di dunia ini. Ada beberapa ahli yang mendefinisikan istilah belajar dengan beberapa kata keterangan yang tidak sama. Untuk dapat memahami dan mempunyai gambaran yang luas, berikut ini diberikan beberapa uraian belajar menurut beberapa ahli:

Menurut W.Gulo belajar adalah suatu proses yang berlangsung di dalam diri seseorang yang mengubah tingkah laku dalam berfikir bersikap dan berbuat. ${ }^{16}$ Sedangkan menurut Syaiful Bahri belajar adalah "suatu kegiatan yang kita lakukan untuk memperoleh sejarah ilmu pengetahuan. ${ }^{17}$ Whittaker, belajar adalah proses tingkah laku yang ditimbulkan atau diubah melalui latihan atau pengalaman. Kimble, belajar adalah perubahan relatif permanen dalam potensi bertindak, yang berlangsung sebagai akibat adanya latihan yang diperkuat. Winkel, belajar adalah aktivitas mental atau psikis, yang berlangsung dalam interaksi aktif dengan lingkungan yang menghasilkan perubahanperubahan dalam pengetahuan, pemahaman, ketrampilan, nilai dan sikap. Sdaffer, belajar merupakan perubahan tingkah laku yang relatif menetap, sebagai hasil pengalaman-pengalaman atau praktik. ${ }^{18}$

Berdasarkan definisi di atas dapat dikatakan bahwa, belajar adalah suatu proses usaha yang dilakukan individu untuk memperoleh

\footnotetext{
${ }^{16}$ Log.Cit W.Gulo.Straregi Belajar Mengajar.PT Grasindo,Jakarta,2002.

${ }^{17}$ Log.Cit Syaiful Bahri Djamarah Drs,Rahasia sukses belajar,Rineka Cipta,Jakarta,2002.

${ }^{18} \mathrm{www}$.google.com/sutsen.facebook/motivasi- belajar.
} 
perubahan tingkah laku yang baru sebagai pengalaman individu itu sendiri.

\section{Faktor-Faktor Yang Mempengaruhi Belajar}

Menurut Suryabrata, faktor-faktor yang mempengaruhi hasil belajar, digolongkan menjadi tiga, yaitu: faktor dari dalam, faktor dari luar dan faktor instrumen. Faktor dari dalam yaitu faktor-faktor yang dapat mempengaruhi belajar yang berasal dari siswa yang sedang belajar. Faktor-faktor ini meliputi: Fisiologi, meliputi kondisi jasmaniah secara umum dan kondisi panca indra. Anak yang segar jasmaninya akan lebih mudah proses belajarnya. Anakanak yang kekurangan gizi ternyata kemampuan belajarnya di bawah anakanak yang tidak kekurangan gizi, kondisi panca indra yang baik akan memudahkan anak dalam proses belajar. Kondisi psikologis, yaitu beberapa faktor psikologis utama yang dapat mempengaruhi proses dan hasil belajar adalah kecerdasan, bakat, minat, motivasi, emosi dan kemampuan kognitif.

Faktor kecerdasan yang dibawa individu mempengaruhi belajar siswa. Semakin individu itu mempunyai tingkat kecerdasan tinggi, maka belajar yang dilakukannya akan semakin mudah dan cepat. Sebaliknya semakin individu itu memiliki tingkat kecerdasan rendah, maka belajarnya akan lambat dan mengalami kesulitan belajar. Bakat individu satu dengan lainnya tidak sama, sehingga menimbulkan belajarnya pun berbeda. Bakat merupakan kemampuan awal anak yang dibawa sejak lahir. Minat individu merupakan ketertarikan individu terhadap sesuatu. Minat belajar siswa yang tinggi menyebabkan belajar siswa lebih mudah dan cepat. Motivasi belajar antara siswa yang satu dengan siswa lainnya tidaklah sama. Adapun pengertian motivasdi belajar adalah Sesuatu yang menyebabkan kegiatan belajar terwujud. Motivasi belajar dipengaruhi oleh beberapa faktor, antara lain: cita-cita siswa, kemampuan belajar siswa, kondisi siswa, kondisi lingkungan, unsurunsur dinamis dalam belajar dan upaya guru membelajarkan siswa. Emosi merupakan kondisi 
psikologi (ilmu jiwa) individu untuk melakukan kegiatan, dalam hal ini adalah untuk belajar. Kondisi psikologis siswa yang mempengaruhi belajar antara lain: perasaan senang, kemarahan, kejengkelan, kecemasan dan lain-lain. Kemampuan kognitif siswa yang mempengaruhi belajar mulai dari aspek pengamatan, perhatian, ingatan, dan daya pikir siswa.

Faktor dari luar yaitu faktor-faktor yang berasal dari luar siswa yang mempengaruhi proses dan hasil belajar Faktor-faktor ini meliputi:

1. Lingkungan alami

Lingkungan alami yaitu faktor yang mempengaruhi dalam proses belajar misalnya keadaan udara, cuaca, waktu, tempat atau gedungnya, alat-alat yang dipakai untuk belajar seperti alat-alat pelajaran. Keadaan udara mempengaruhi proses belajar siswa. Apabila udara terlalu lembab atau kering kurang membantu siswa dalam belajar. Keadaan udara yang cukup nyaman di lingkungan belajar siswa akan membantu siswa untuk belajar dengan lebih baik. Waktu belajar mempengaruhi proses belajar siswa misalnya: pembagian waktu siswa untuk belajar dalam satu hari. Cuaca yang terang benderang dengan cuaca yang mendung akan berbeda bagi siswa untuk belaar. Cuaca yang nyaman bagi siswa membantu siswa untuk lebih nyaman dalam belajar. Tempat atau gedung sekolah mempengaruhi belajar siswa. Gedung sekolah yang efektif untuk belajar memiliki ciri-ciri sebagai berikut: letaknya jauh dari tempat-tempat keramaian (pasar, gedung bioskop, bar, pabrik dan lain-lain), tidak menghadap ke jalan raya, tidak dekat dengan sungai, dan sebagainya yang membahayakan keselamatan siswa. Alat-alat pelajaran yang digunakan baik itu perangkat lunak (misalnya, program presentasi) ataupun perangkat keras (misalnya Laptop, LCD).

2. Lingkungan sosial 
Lingkungan sosial di sini adalah manusia atau sesama manusia, baik manusia itu ada (kehadirannya) ataupun tidak langsung hadir. Kehadiran orang lain pada waktu sedang belajar, sering kali mengganggu aktivitas belajar. Dalam lingkungan sosial yang mempengaruhi belajar siswa ini dapat dibedakan menjadi tiga, yaitu: (1) lingkungan sosial siswa di rumah yang meliputi seluruh anggota keluarga yang terdiri atas: ayah, ibu, kakak atau adik serta anggota keluarga lainnya, (2) lingkungan sosial siswa di sekolah yaitu: teman sebaya, teman lain kelas, guru, kepala sekolah serta karyawan lainnya, dan (3) lingkungan sosial dalam masyarakat yang terdiri atas seluruh anggota masyarakat. ${ }^{19}$

\section{Motivasi Belajar}

Seperti telah dijelaskan dimuka bahwa motivasi dan belajar adalah suatu rangkaian yang tidak terlepas. Jadi motivasi belajar adalah proses menuju sukses dengan keinginan dan ide-ide yang terexspresi lewat dorongan dan dukungan, yang utama dari keluarga. Menurut Hermine Marshall motivasi belajar adalah kebermaknaan nilai dan keuntungan keuntungan kegiatan belajar, belajar tersebut cukup menarik bagi siswa untuk melakukan kegiatan belajar. Pendapat lain motivasi belajar itu ditandai oleh jangka kualitas keterbatasan di dalam pelajaran dan kesanggupan untuk melakukan proses belajar. ${ }^{20}$

Sedangkan Wlodkowski dalam Suciati, menjelaskan motivasi sebagai "suatu kondisi yang menyebabkan atau menimbulkan perilaku tertentu, serta yang memberi arah dan ketahanan (persistence) pada tingkah laku tersebut. ${ }^{21}$ Sementara Ames dan Ames dalam Suciati, menjelaskan motivasi sebagai perspektif yang dimiliki seseorang

\footnotetext{
${ }^{19} \mathrm{Ibid}, 83$.

${ }^{20} \mathrm{www}$.google.com/teori motivasi

${ }^{21} \mathrm{www}$.google.com/pengertian-motivasi/fb
} 
mengenai dirinya sendiri dan lingkungannya. Menurut definisi ini, konsep diri yang positif akan menjadi motor penggerak bagi kemauan seseorang. ${ }^{22}$

Dalam proses belajar motivasi seseorang tercermin melalui ketekunan yang tidak mudah patah untuk mencapai sukses, meskipun dihadang banyak kesulitan. Motivasi juga ditunjukkan melalui intensitas unjuk kerja dalam melakukan suatu tugas. Mc Clelland menunjukkan bahwa motivasi berprestasi (achievement motivation) mempunyai kontribusi sampai 64 persen terhadap prestasi belajar. ${ }^{23}$ Dari berbagai teori motivasi yang berkembang, Keller telah menyusun seperangkat prinsip-prinsip motivasi yang dapat diterapkan dalam proses pembelajaran, yang disebut sebagai model ARCS, yaitu:

1. Attention (Perhatian)

Perhatian peserta didik muncul karena didorong rasa ingin tahu. Oleh sebab itu, rasa ingin tahu ini perlu mendapat rangsangan, sehingga peserta didik akan memberikan perhatian selama proses pembelajaran. Rasa ingin tahu tersebut dapat dirangsang melalui elemen-elemen yang baru, aneh, lain dengan yang sudah ada, kontradiktif atau kompleks. Apabila elemen-elemen tersebut dimasukkan dalam rencana pembelajaran, hal ini dapat menstimulus rasa ingin tahu peserta didik. Namun, perlu diperhatikan agar tidak memberikan stimulus yang berlebihan, untuk menjaga efektifitasnya.

2. Relevance (Relevansi)

Relevansi menunjukkan adanya hubungan materi pembelajaran dengan kebutuhan dan kondisi peserta didik. Motivasi peserta didik akan terpelihara apabila mereka

\footnotetext{
22 Ibid, 71.

${ }^{23} \mathrm{Ibid}, 69$.
} 
menganggap bahwa apa yang dipelajari memenuhi kebutuhan pribadi atau bermanfaat dan sesuai dengan nilai yang dipegang.

Kebutuhan pribadi (basic need) dikelompokkan dalam tiga kategori yaitu motif pribadi, motif instrumental dan motif kultural. Motif nilai pribadi (personal motif value), menurut McClelland mencakup tiga hal, yaitu; kebutuhan untuk berprestasi (needs for achievement), kebutuhan untuk berkuasa (needs for power), dan kebutuhan untuk berafiliasi (needs for affiliation).

Sementara nilai yang bersifat instrumental, yaitu keberhasilan dalam mengerjakan suatu tugas dianggapm sebagai langkah untuk mnecapai keberhasilan lebih lanjut. Sedangkan niali kultural yaitu apabila tujuan yang ingin dicapai konsisten atau sesuai dengan nilai yang dipegang oleh kelpmpok yang diacu peserta didik, seperti orang tua, teman, dan sebagainya.

3. Confidence (Percaya diri)

Merasa diri kompeten atau mampu, merupakan potensi untuk dapat berinteraksi secara positif dengan lingkungan. Prinsip yang berlaku dalam hal ini adalah bahwa motivasi akan meningkat sejalan dengan meningkatnya harapan untuk berhasil. Harapan ini seringkali dipengaruhi oleh pengalaman sukses di masa lampau. Motivasi dapat memberikan ketekunan untuk membawa keberhasilan (prestasi), dan selanjutnya pengalaman sukses tersebut akan memotivasi untuk mengerjakan tugas berikutnya.

4. Satisfaction (Kepuasan)

Keberhasilan dalam mencapai suatu tujuan akan menghasilkan kepuasan. Kepuasan karena mencapai tujuan dipengaruhi oleh konsekuensi yang diterima, baik yang berasal 
dari dalam maupun luar individu. Untuk meningkatkan dan memelihara motivasi peserta didik, dapat menggunakan pemberian penguatan (reinforcement) berupa pujian, pemberian kesempatan, dsb. 24

Hal ini pengkataan motivasi belajar dapat dilihat dari: Frekuensi belajar anak frekuensi belajar tediri dari dua kata adalah frekuensi dan belajar menurut kamus besar bahasa Indonesia frekuensi adalah kekerapan, jarang kerapnya. Sedangkan belajar adalah berusaha berlatih untuk mendapatkan pengetahuan secara efektif dan efisien.

Intensitas belajar menurut kamus besar bahasa Indonesia intensitas berarti keadaantingkatan atau ukuran intensnya, dengan demikian intens belajar adalah keadaan tingkatan untuk mendapatkan pengetahuaan secara efektif dan efisien. Kontinuitas belajar anak keadaan berkesinambungan untuk mendapatkan pengetahuan secara efektif dan efisien. ${ }^{25}$

\section{Kesimpulan}

Komunikasi merupaka sebuah proses hubungan antar seseorang dengan yang lainnya. Dalam keluarga dibutuhkan sebuah komunikasi yang baik antara orang tua dan anak baik secara verbal atau non-verbal agar dapat memunculkan sebuah motivasi pada anaknya.

\section{Daftar Pustaka}

Bahri Djamarah Syaiful, 2002, Rahasia sukses belajar, Jakarta: Rineka Cipta.

Bimo, 1997, Bimbingan Penyuluhan di Sekolah, Yogyakarta: Yayasan Penerbit Psikologis UGM.

Cangara, Hafied, 2002, Pengantar Ilmu Komunikasi, Jakarta: Raja Grafindo Persada.

\footnotetext{
${ }^{24}$ Ibid, 81.

${ }^{25} \mathrm{Ibid}, 85$.
} 
Gordon, Thomas, 1991, Menjadi Orang Tua efektif, Petunjuk Terbaru Mendidik Anak yang Bertanggung Jawab, Jakarta: PT Gramedia Pustaka Utama.

Gulo W, 2002, Straregi Belajar Mengajar, Jakarta: PT Grasindo.

Hadari Nawawi, 1991, Metode Penelitian Bidang social, Yogyakarta: UGM University Press, Cetakan V.

Liliweri Alo, 1997, Komunikasi Antar Pribadi, Bandung: PT. Citra Aditia Bakti.

Shochib, Moh, 1998, Pola Asuh Orang Tua. Jakarta: PT. Rineka Cipta.

Singarimbun Masri dan Effendi Sofwan, 1989, Metode Perumusan Masyarakat, Jakarta: PT. Gramedia Pustaka Utama. 
Zulin Nurchayati

160 | Bidayatuna, Vol. 01 No. 02 Oktober 2018 